\title{
Sources of Job Stress in Police Work in a Developing Country
}

\author{
R. S. Suresh ${ }^{1}$, R. N. Anantharaman ${ }^{2}$, Ajitha Angusamy ${ }^{2} \&$ Jaya Ganesan $^{2}$ \\ ${ }^{1}$ Software Paradigms Infotech, Mysore, India \\ ${ }^{2}$ Faculty of Business, Multimedia University, Melaka, Malaysia \\ Correspondence: R. N. Anantharaman, Faculty of Business, Multimedia University,75450 Jalan Ayerkeroh \\ Lama, Melaka, Malaysia. Tel: 60-6-252-3877. E-mail: r.n.anantharaman@mmu.edu.my
}

Received: April 9, 2013

Accepted: April 22, 2013

Online Published: June 17, 2013

doi:10.5539/ijbm.v8n13p102

URL: http://dx.doi.org/10.5539/ijbm.v8n13p102

\begin{abstract}
An attempt was made to determine which job events are perceived as significant sources of stress in police work. The Police Stress Inventory was developed based on the interviews with police staff and experts in police administration for this study. The questionnaire was administered to a random sample of 220 police personnel. The respondents rated the job situations as least stressful $(0 \%)$ to most stressful $(100 \%)$. They consider the organizational and social aspects of their job are more stressful especially round the clock duty, lack of time for family, political pressures from outside and inadequate facilities. Results indicate that stress is due more to organisational factors than to physical hazards on the job. Efforts should be made by police administration to take corrective measures such as changes within organization and improving training programs. Efforts should be made by police administration to take corrective measures such as changes within organization and improving training programs.
\end{abstract}

Keywords: job stress, police personnel, developing country, implications

\section{Introduction}

There is an increasing preoccupation with stress within workplace (Collin \& Gibbs, 2003). Research has implicated job stress as an important causal agent in health problems such as coronary heart disease, gastro-intestinal malfunction, dermatological problems, severe nervous conditions, insomnia, and increased levels of destructive stress hormones, post traumatic stress disorder suicide and other physical problems (Ramachandruni et.al., 2004; Karen et.al., 2006; Kivimak et.al., 2006; Violanti, 2008; Wang, 2007).

Human service professions such as medicine, social work, nursing, teaching, public safety, child care and occupational therapy are viewed as high stress occupations (Cherniss, 1980). Individuals in these professions work intensively, intimately and continually with people who have serious physical, mental, emotional and social problems. Every person is subject to stress, police staff are at greater risk than other people (Mc Cafferty et.al., 1990). Police work is considered as most stressful occupation (Sever \& Cinoglu, 2010; Buker \& Wiecko, 2007; Volanti et.al., 2006; Yesilorman, 2003; Liberman et. al., 2002; Burke, 1993; Crank \& Caldero, 1991; Coman \& Evans, 1991; Sigler et.al., 1991; Kroes, 1976). Police work is regarded as inherently stressful because of the personal risk of exposure to confrontation and violence and the everyday involvement in a variety of traumatic incidents (Collins \& Gibbs, 2003) Several authors opine that job stress is the crucial problem confronting police officers. (Selye, 1978; Fell et.al., 1980; Kroes, 1976; Kroes, et.a.1,1974; Silbert, 1982; Stratton, 1978a).

Higher rates of morbidity and mortality was observed in police work force than in many other occupations due to job stress (Doctor et.al 1994). The police staff have poor health (Cooper \& Davidson, 1987; Fletcher, 1988; Kirkcaldy et.al., 1995), frequently absent from work (Wright \& Saylor, 1991) and experience burnout (Brown et.al., 1996; Burke \& Deszca, 1986; Crank et.al., 1995; Lord 1996; Stotland \& Pendleton, 1989). The police personnel are found to be dissatisfied with their jobs (Norvel et.al., 1998). It has been found that because of their weak organizational commitment, police staff, may not fully invest themselves in their work (Kop et.al., 1999; Malloy \& Mays, 1984; Stevenson, 1988). When these police employees have too much occupational stress they suffer from increased chronic stress, heart diseases depression, stomach disorders, alcohol and drug abuse, divorce and suicide attempts (Anshel, 2000; Biggam et.al., 1977; Dietrich, 1989; Lord, 1996; Walker, 1997; Blackmore, 1978; Chenet.al., 2006). Rates of depression were found to be higher in police than general 
population (Chen et.al 2006). It was found that stress not only affect police staff, but also their families (Zakir \& Murat, 2011; Sever \& Cinoglu, 2010; Hawassy, 1994; Scrivner, 1994). The police officers relatively have high rates of suicide (Friedman, 1967; Kelling \& Pate, 1975).

There have been many studies regarding the intensity, prevalence, sources and effect of stress among police staff (Aroon, 2000; Aldag \& Brief, 1979; Bannerman, 1997; Brooks \& Piquero, 1998; Geick, 1998; Hilgren et.al., 1976; Kroes et.al., 1974; Laufesweiler-Dwyer \& Dwyer, 2000; Lord, 1996; Morash \& Haarr, 1995; Morash et.al., 2006; Sewell, 1981; Silbert, 1982; Singleton \& Teahan, 1978; Violanti \& Aron, 1993, 1994; Washington, 1981; Wexler \& Logan, 1983; Whitte \& Marino, 1983). Research on police stress has not kept pace with the research on occupational stress in general (Ellison, 2004). Exaggeration of physical dangers of police work are regularly seen in the mass media particularly on television and in films. Paradoxically however, recent research suggests that stress is due more to organizational and psychological factors than to physical risks. Little or no attention is focused on job related stress that contributes to alcoholism, divorce, and suicide rates that are higher among police officers than among other occupational groups.

If a public opinion poll asked what type of work is most stressful, a large number of people would be likely to say "being a cop" (Maslach \& Jackson, 1979). Police staff are exposed to many sources of stress and law enforcement is particularly stressful occupation (Alkus \& Padesky, 1983; Anshell 2000; Anshel et.al., 1997; Paton \& Violanti, 1997; Violanti \& Aron, 1993, 1994).The debilitating stressors of police work have very serious implications including the impaired functioning of individuals and a deterioration of performance which can result in a corresponding deterioration in response to the needs of the community that the police are expected to serve (Davidson \& Veno,1980; Sewel, 1984). It is very important to understand the sources of police occupational stress and suggest strategies to reduce stress or if not assist police personnel in coping with them (Morsch et. al., 2006). An attempt is made to find the sources of stress among police officials in a developing country like India where the ratio of police and public is very low. Most studies on occupational stress have been conducted quantitatively. No qualitative research has been conducted (Beehr \& Glazer, 2001; Glazer \& Beehr, 2005). The present study tries to determine which stressors are most salient in police occupation. It aims to find out sources of stress and rank them in terms of importance viz most stressful to least one. This is relevant and necessary to develop prevention strategies.

\section{Methodology}

\subsection{Sample}

The sample consisted of 450 police personnel which included Inspectors, Sub-inspectors, Head constables and Constables belonging to both sexes. The sample was randomly drawn from six police ranges in Chennai city. Two hundred and forty one questionnaires out of 450 questionnaires were returned of which 220 were found to be usable yielding a response rate of 53.6 percent. Twenty one of these responses were excluded for analyses because they were incomplete. The final sample consisting of 220 individuals contained 201 men and 19 women. The mean age was 40.2 years and the standard deviation 7 years (range 23-57). Ninety percent of them were married. The bulk of the sample (66\%) comprised of Sub-Inspectors. About $46 \%$ of the sample had studied only up to high school. An almost equal number (45\%) of them were graduates. The respondents had been in service from 2 to 37 years with a mean of 17.6 years. Eighty percent of the sample belonged to the Law and Order branch. A substantial number of respondents $(75 \%)$ were engaged in regular program of exercise ranging from once a week to everyday. More than ninety percent of the sample had not availed sick leave in the past month but the figure slumped to $67 \%$ while considering sick leave not availed in the past year.

Thus the typical respondents from this sample of police personnel was male, married, aged about 40 years, high school educated, engaged in a regular program of exercise once a week, had been employed for about 18 years and was currently working as Sub-Inspectors in Law and Order branch of Madras city police.

\subsection{Instrument}

In addition to demographic items, respondents completed the Police Stress Inventory (PSI). Developed specifically for this studty, the PSI consists of 80 job situations that police officers are expected to encounter in the performance of their duties. Each job situation was derived from interviews with experts at the National Police Academy, Bureau of Police Research and Development and Police training College including several senior police officers in Madras city and from lists of specific situations and events in the literature that appeared to adversely affect police officers (Hillgren, et.al 1976; Kroes \& Gould, 1979; Kroes, et.al,1974; Kroes, et. al,1974;Margolis, et.al., 1974). Based on the discussion and interviews with police officials and literature search 80 job situations were selected for this study. 
Respondents were asked to rate (on a percentage scale) each job event, as "stressful", according to the magnitude of stress they perceive to be associated with each job event. Evidence indicates that the PSI is both a valid and reliable measure of job stress among police personnel.

\section{Results and Discussion}

\subsection{Stress Ratings of Police Job Events}

Table 1 lists the 80 job events in order of their ratings from most to least stressful. All the 80 job events evoked very wide variations in response ranging from 0 to 100 , indicating diversity of reactions to each item.

Table 1. Job events ranked from most to least stressful

\begin{tabular}{|c|c|c|c|}
\hline \multirow{2}{*}{ JOB EVENT } & \multicolumn{2}{|c|}{$\mathrm{N}=220$} & \multirow{2}{*}{ RANK } \\
\hline & Mean & S.D. & \\
\hline Never off-duty or round the clock duty & 53.83 & 33.21 & 1 \\
\hline Lack of time to spend with family & 52.24 & 31.38 & 2 \\
\hline Political pressure from outside the department & 48.95 & 28.85 & 3 \\
\hline Inadequate salary/facilities & 48.85 & 32.38 & 4 \\
\hline Political pressure from within the department & 48.37 & 27.16 & 5 \\
\hline Bandobust( Providing security to VIPs) & 46.34 & 31.55 & 6 \\
\hline Public criticism of police & 45.42 & 25.19 & 7 \\
\hline Court leniency towards criminals & 44.92 & 27.66 & 8 \\
\hline Using poor quality equipment & 44.59 & 28.02 & 9 \\
\hline Hostile witnesses & 44.45 & 29.85 & 10 \\
\hline Excessive paper work & 43.02 & 30.11 & 11 \\
\hline $\begin{array}{l}\text { Legal loop holes leading to case dismissals, acquittals and unfavorable } \\
\text { verdicts }\end{array}$ & 42.76 & 27.98 & 12 \\
\hline Insulting experience on the job & 42.25 & 31.07 & 13 \\
\hline Lack of recognition for good work done & 41.55 & 24.65 & 14 \\
\hline Arresting an influential person & 41.12 & 29.74 & 15 \\
\hline Insufficient staff to handle critical jobs & 40.87 & 26.68 & 16 \\
\hline Strict departmental regulations & 40.36 & 31.26 & 17 \\
\hline Ineffectiveness of the judicial system & 40.15 & 25.62 & 18 \\
\hline Harassed by superior & 39.51 & 30.39 & 19 \\
\hline Time pressure & 39.30 & 27.61 & 20 \\
\hline Distorted, harsh reports by press & 38.57 & 28.12 & 21 \\
\hline Indecent public view of profession & 37.33 & 31.45 & 22 \\
\hline Dealt too many cases in a single day & 37.05 & 26.46 & 23 \\
\hline Working with inefficient staff & 35.77 & 27.60 & 24 \\
\hline Working against one's best judgment & 35.70 & 28.48 & 25 \\
\hline Doing non-police work & 35.36 & 31.74 & 26 \\
\hline Blamed for other's fault & 34.76 & 27.68 & 27 \\
\hline Conducting raids & 34.73 & 29.19 & 28 \\
\hline Inadequate support by the department & 34.18 & 28.78 & 29 \\
\hline Influx of extremists & 33.56 & 29.66 & 30 \\
\hline Lack of timely promotions & 33.30 & 33.06 & 31 \\
\hline Job conflict (book knowledge vs actual situation) & 33.23 & 26.04 & 32 \\
\hline Ill treatment of police in courts & 32.89 & 27.18 & 33 \\
\hline Confrontation with aggressive mobs & 32.65 & 28.24 & 34 \\
\hline Inadequate support from immediate superior & 32.58 & 28.46 & 35 \\
\hline Risk of making errors & 32.13 & 26.98 & 36 \\
\hline Doing" unpleasant tasks" & 32.05 & 28.57 & 37 \\
\hline Given responsibility without the necessary authority & 31.90 & 27.46 & 38 \\
\hline
\end{tabular}


Table 2. Job events ranked from most to least stressful

\begin{tabular}{|c|c|c|c|}
\hline \multirow{2}{*}{ JOB EVENT } & \multicolumn{2}{|c|}{$\mathrm{N}=220$} & \multirow{2}{*}{ RANK } \\
\hline & Mean & S.D. & \\
\hline Wearing a uniform for long hours & 30.96 & 28.05 & 39 \\
\hline Co-worker killed in the line of duty & 30.90 & 29.60 & 40 \\
\hline Retaliation by offenders/powerful others & 30.71 & 25.73 & 41 \\
\hline Threat to life & 30.23 & 27.58 & 42 \\
\hline Difficulty in getting along with superior(s) & 29.74 & 27.67 & 43 \\
\hline Using physical force & 29.72 & 25.98 & 44 \\
\hline Communication and feedback problems within the department & 29.44 & 24.76 & 45 \\
\hline Misuse of power by superior & 29.41 & 30.26 & 46 \\
\hline Misuse of power by colleague & 29.27 & 26.48 & 47 \\
\hline Responsibility for people & 28.83 & 29.47 & 48 \\
\hline No clear guidelines regarding one's role or duty & 28.20 & 25.87 & 49 \\
\hline Lack of participation in vital decisions & 27.99 & 24.38 & 50 \\
\hline Working against caste, communal and /or religious sentiments & 27.14 & 28.05 & 51 \\
\hline Lack of opportunities for updating knowledge & 27.13 & 26.14 & 52 \\
\hline Ineffectiveness of the correctional system & 27.08 & 26.79 & 53 \\
\hline Insubordination & 26.77 & 26.12 & 54 \\
\hline Unfavorable government decisions/policies & 26.00 & 25.06 & 55 \\
\hline Court appearances in off-duty hours & 25.85 & 21.66 & 56 \\
\hline Under utilization of skills & 25.64 & 24.12 & 57 \\
\hline Searching or frisking a suspect & 25.63 & 24.21 & 58 \\
\hline Taking disciplinary action against subordinate & 25.45 & 25.01 & 59 \\
\hline Gender discrimination in the department & 25.35 & 24.88 & 60 \\
\hline Poor relations with co-workers & 24.98 & 20.17 & 61 \\
\hline Assignment of new unfamiliar duties & 24.67 & 21.02 & 62 \\
\hline VIP Security /Escort & 24.09 & 21.49 & 63 \\
\hline Exposure of the injured/dead & 24.00 & 20.92 & 64 \\
\hline High speed chases & 23.93 & 21.50 & 65 \\
\hline Custodial death & 23.28 & 20.19 & 66 \\
\hline Frequent changes from boring to demanding activities & 23.02 & 22.94 & 67 \\
\hline Inadequate or poor supervision & 22.76 & 21.42 & 68 \\
\hline Recidivism & 22.44 & 20.82 & 69 \\
\hline Juvenile delinquency & 22.26 & 21.22 & 70 \\
\hline Testifying in court & 21.94 & 18.20 & 71 \\
\hline Opening fire & 21.74 & 19.75 & 72 \\
\hline Grievous hurt while on the job & 21.65 & 17.77 & 73 \\
\hline Harassed by colleague & 20.48 & 19.14 & 74 \\
\hline Exposure to people in pain & 19.20 & 18.14 & 75 \\
\hline Minor physical injury while on the job & 19.04 & 16.74 & 76 \\
\hline Physical assault on self & 18.20 & 17.09 & 77 \\
\hline Handling fire arms & 17.37 & 16.41 & 78 \\
\hline Exhumation & 14.49 & 13.11 & 79 \\
\hline Problems with other branches of policies & 13.61 & 11.36 & 80 \\
\hline
\end{tabular}

The two job events "never off duty or round the clock duty (Mean $=53.83)$ and lack of time to spend with family (Mean = 52.24)" are among the most potent sources of stress. Could it be because of the ratio of police personnel to public is very low in India, when compared to developed countries? The police staff work for more than 12 hours a day and they can be called to duty time even during holidays. Since police work is 24 hours duty and some of them are posted at the senior officers residences to provide services and security. They are forced to work for many hours in a day and thus a less number of staff are available provide service to the public. Because they have to work many hours they have very little time to be with family. This may result in strained relationships with family members, leading to alcoholism and divorce.

The political pressure from outside the police department is the third important source of stress. The police 
personnel may be prevented from taking action against persons for criminal behavior because of their political connections (the ruling party may bring pressure on the police department to go slow or prevent from taking action). Inadequate salary / facilities is the fourth major source of stress followed by political pressure within the department. Providing security to VIPs and public meetings addressed by political and religious leaders is listed as the sixth major source. When the political and religious meetings are organized, police staff deployed to provide security. Many times there may by clashes in the meetings due to leaders' speeches. The police staff have to be very vigilant and tactful in dealing with masses.

Public criticism is another source followed by court leniency towards criminals, poor equipment and hostile witness. These are followed by other sources of job stress. The public criticism of police is the seventh major source of police stress. The mass media especially cinema depicts the police force in a very bad manner leading to poor public image. Court leniency towards criminals is the next major source of stress. The least stressful ones are problems with other branches of police, exhumation, handling fire arms, physical assault on self, minor physical injury while on the job, exposure to people in pain, harassed by colleagues, grievous hurt while on job, opening fire, testifying in the court and juvenile delinquency.

Overall out of 80 sources of job stress perceived by police personnel 40 of them can be categorized as organizational or work place problems. Workplace problems are distinct because they are related to organization. They indicate the troublesome features of the work organization. They include round-clock duty, no time for family, inadequate salaries / facilities, negative interaction with other police staff, poor equipment, no recognition, too many cases, insufficient staff and harasement. The present results are consistent with the findings of Morash \& Haarr (1995), Wexler \& Logan (1983), White \& Marino (1983), Brown et. al., (1996), Crank et.al., (1995), Hurrell (1995), Kirkcaldy et.al., (1995), Edalwich (1980), Kroes (1985), Reinecke et.al., (2007), and Mathias et.al., (2010). The police staff have not mentioned the crime rate, population and the area they are serving as sources of job stress though in India these are most important aspects of police service.

The average policeman took pride in his work and in his special training. He perceived himself as and is in fact, a trained law enforcement specialist. Within this framework he develops a certain perception of himself, that of a professional. Psychologically, it is very threatening and uncomfortable when a discrepancy occurs between one's self-perception and one's perception by others. The officer perceives himself as a knowledgeable expert providing a vital service to the community, but he is often treated as if he is an enemy to the well-being of the community.

Though policemen face stressors common to other work groups, there is an additional important group of stressors not faced by other occupational groups. The very fact of being a policeman sets the officer apart from the rest of the community. Groups within society react to the policeman not as an individual but with a stereotype. Even off the job and out of uniform, the policeman must accept prejudice, fear, suspicion, and sometimes even hostility from large segment of society. Thus, police work becomes one of the few jobs which has a potent adverse effect on the total life of the worker. That is, the policeman's job affects his own personal social life, his family's social life, his children's perception of him as a father, etc. Finally, police work is among those very few occupations in which the employee is asked to risk his life and in which he may face physical danger at any time. These additional stressors not only have a significant impact of their own, but they likely serve to reduce the frustration tolerance necessary for handling other job stressors.

Therefore, from the point of view of the effective functioning of the police department, as well as the effective functioning of the policeman, serious attempts at reduction of specific job stressors are warranted. When stress is too much it may lead to burnout of the police staff. Burnout is likely to occur in human service professions such as social workers, nurses, teachers, lawyers, physicians and police officers. This is partly due to high stress environment, emotional involvement and outcomes that workers may be independent of the effort exerted by the working individual. In conclusion, there appear to be three broad ways of dealing with occupational stress. Firstly, majority of perceived sources of job stress are related to workplace problems, changes may be made within the police department to prevent stress and its effects. Secondly, improved training may alleviate stress by increasing self-efficacy and coping skills. Thirdly, departmental mental-health programs may be implemented to treat stress-related problems as they occur. The police organization can also introduce steps to improve the public image of police staff.

\section{References}

Aaron, J. (2000). Stress and coping in police officers. Police Quarterly, 3, 428-450. http://dx.doi.org/10.1177/109861110000300405

Aldag, R. J., \& Brief, A. P. (1979). Examination of a measure of higher-order need strength. Health Relations, 


\section{2, 705-718. http://dx.doi.org/10.1177/001872677903200805}

Alkur, S., \& Padesky, C. (1983). Social problems of police officers, stress related issues and interventions. Counselling Psychologist, 11, 55-64. http://dx.doi.org/10.1177/0011000083112010

Anshel, M. H. (2000). A conceptual model and implications for coping with stressful events in police work. Criminal Justice and Behavior, 27, 375-400. http://dx.doi.org/10.1177/0093854800027003006

Anshel, M. H., Robertson, M., \& Caputi, P. (1997). Sources of acute stress and their appraisals and repraisals among Australian police as a function of previous experience. Journal of Occupation and Organisational Psychology, 70, 525-549. http://dx.doi.org/10.1111/j.2044-8325.1997.tb00653.x

Bannerman, E. D. (1997). Female Police officers: The relationship between social support, interactional style, and occupational stress and strain. Vancouver: Simon Frasier University.

Beehr, A. T., \& Glazer, S. (2001). A cultural perspective of social support in relation to occupational stress. In Pamela, L. P., \& Daniel, C. G. (Eds.), Exploring theoretical Mechanisms and Perspectives (Research in Occupational Stress and Well-being, Vol. 1 pp. 97-142). Emerald Publishing Limited.

Biggam, F. H., Power, K. G., \& MacDonald, R. R. (1997). Self-perceived occupational stress and distress in a Scottish police force. Work and Stress, 11, 118-133. http://dx.doi.org/10.1080/02678379708256829

Blackmore. (1978). Are police allowed to have problems of their own? Police Magazine, 1(3), 47-55.

Breznitz, S., \& Goldberger, L. (1982). Stress research at a cross roads. In Goldberger \& S. Brenitz (Eds.), Handbook of stress: Theoretical and Clinical aspects. New York: The Free Press.

Brooks, L. W., \& Piquero, N. L. (1998). Police stress: Does department size matter? Policing: An International

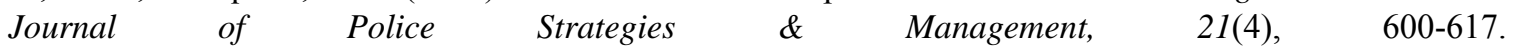
http://dx.doi.org/10.1108/13639519810241647

Brown, J., Cooper, C. L., \& Kirkcaldy, B. (1996). Occupational stress among senior police officers. British Journal of Psychology, 87, 31-45. http://dx.doi.org/10.1111/j.2044-8295.1996.tb02575.x

Buker, H., \& Wiecko, F. (2007). Are causes of police stress global: Testing the effects of common police stressors on the Turkish National Police. Policing: An International Journal of Police Strategies and Management, 30(1/2), 291-309. http://dx.doi.org/10.1108/13639510710753270

Burke, R. J., \& Deszca, E. (1986). Correlates of psychological burnout phases among police officers. Human Relations, 39, 487-502. http://dx.doi.org/10.1177/001872678603900601

Burke, R. J. (1993). Work-Family Stress Conflict, Coping and Burnout in Police Officers. Stress Medicine, 9, 171-180. http://dx.doi.org/10.1002/smi.2460090308

Chen, H. C., Chou, F. H., \& Wu, H. C. (2006). A survey of quality of life and depression for police officers in Kuohsiung. Taiwan Quality of Life Research, 15, 925-932. http://dx.doi.org/10.1007/s11136-005-4829-9

Collins, P. A., \& Gibbs, A. C. C. (2003). Stress in police officers: a study of the origins, prevalence and severity of stress-related symptoms within a country police force. Journal of Occupational Medicine, 53, 256-264. http://dx.doi.org/10.1093/occmed/kqg061

Coman, J. G., \& Berry, J. E. (1991). Stressors Facing Australian Police in 1990s. Police Studies, 14(1/4), $153-65$.

Cooper, C. L., \& Davidson, M. (1987). Sources of stress at work and their relation to stressors in non-working environments. In R. Kalimo, M. A. El-Batawi, \& C. L. Cooper (Eds.), Psychological factors at work and their relation to health (pp. 99-123). Geneva: World Health Organization.

Crank, P. J., \& Caldero, M. (1991). The Production of Occupational Stress in Medium Sized Police Agencies: A Survey of Line Officers in Eight Municipal Departments. Journal of Criminal Justice, 19(1/4), 339-349. http://dx.doi.org/10.1016/0047-2352(91)90031-P

Crank, J., Regoli, R., \& Culbertson, R. (1995). Institutional and organizational antecedents of role stress, work alienation, and anomie among police executives. Criminal Justice and Behavior, 22, 152-167. http://dx.doi.org/10.1177/0093854895022002004

Davidson, M. J., \& Veno, A. (1980). Stress and the Policeman. In C. L. Cooper and J.Marshall (Eds.), White Collar and Professional Stress. New York: John Wiley and Sons, Ltd.

Dietrich, J. (1989). Helping subordinates face stress. Police Chief, 56, 44-47. 
Doctor, R. S., Curtis, D., \& Issacs, G. (1994). Psychiatric morbidity in policemen and the brief psychotherapeutic intervention-a pilot study. Stress Medicine, 10(3), 151-157. http://dx.doi.org/10.1002/smi.2460100304

Edelwich, J. (1980). Burn-out. Human Sciences Press. New York.

Ellison, K. W., \& Genz, J. (1983). Stress and the police officer. Sprongfield, IL: Charles C. Thomas.

Fell, R. D., Richard, W. C., \& Wallace, W. L. (1980). Psychological job stress and the police officer. Journal of Police Science and Administration, 8(2), 139-144.

Fletcher, B. C. (1988). The epidemiology of occupational stress. In C.L. Cooper \& R. Payne (Eds.), Causes, coping and consequences of stress at work (pp.12-57). Chicester, UK: Wiley.

Friedman, P. (1967). Suicide among Police. In Edwin S. Schneidman (Ed.), Essays in Self-Destruction (pp. 414-449). Science House: New York.

Geick, E. (1998). Occupational stress of female police officers: An empirical investigation. Texas A \& M University.

Glazer, S., \& Beehr, A. T. (2005). Consistency of implications of three role stressors across four Countries. Journal of Organizational Behaviour, 26(5), 467-487. http://dx.doi.org/10.1002/job.326

Gul, S. K. (2008). Police Job Stress in the USA. Turkish Journal of Police Studies (Polis Bilimleri Dergisi), 10(1), 1-13.

Havassy, J. V. (1994). Police Job Stress in the 1990s and Its Impact on the Family. In J. T. Reese \& E. Scrivner (Eds.), Law Enforcement Famililes: Issues and Answers. Washington, DC: U. S. Department of Justice, Federal Bureau of Investigation.

Hillgren, J. S., Bond, R., \& Jones, S. (1976). Primary Stressors in Police Administration and Law Enforcement. Journal of Police Science and Administration, 4(4), 445-449.

Hurrell, J. J. (1995). Police work, occupational stress, and individual coping. Journal of Organizational Behavior, 16, 27-34. http://dx.doi.org/10.1002/job.4030160105

Juniper, D. (1996). Stress in police force. Police Journal, 69, 61-69.

Karen, A., Matthews, S. Z., Diane, C. T., \& Mary, A. W. (2006). Blood Pressure Reactivity to Psychological Stress and Coronary Calcification in the Coronary Artery. Risk Development in Young Adults Study Hypertension, 47, 391-395.

Kelling, G., \& Antony, M. P. (1975). The person-role fit in policing: The current Knowledge. In Kroes, W. H. and Hurrell, J. J. (Eds), Job Stress and the Police Officer: Identifying Stress Reduction Techniques. U. S Department of H. E. W., Washington, DC.

Kirkcaldy, B., Cooper, C. L., \& Ruffalo, P. (1995). Work stress and health in a sample of U.S. Police. Psychological Reports, 76, 700-702. http://dx.doi.org/10.2466/pr0.1995.76.2.700

Kivimaki, M., Virtanen, M., Elovainio, M., Konvonen, A., Vaananen, A., \& Vahtera, J. (2006). Work Stress in the etiology of coronary heart disease: a meta-analysis. Scandinavian Journal of Work Environment, 32(6), 431-442. http://dx.doi.org/10.5271/sjweh.1049

Kop, N., Euwema, M., \& Schaufeli, W. (1999). Burnout, job stress and violent behavior among Dutch police officers. Work and Stress, 13, 326-340.

Kroes, H. W. (1985). Society's Victim, The Policeman: An Analysis of Job Stress in Policing. Illinios: Charles C. Thomas. http://dx.doi.org/10.1080/02678379950019789

Kroes, W. H., \& Gould, S. (1979, spring). Job stress in policemen: An empirical study. Police Stress, 9-10.

Kroes, W. H., Margolis, B., \& Hurrell, J. J. (1974). Job stress in police administrators. Journal of Police Science and Administration, 2(4), 381-387.

Laufesweiler-Dwyer, D. L., \& Dwyer, G. R. (2000). Profiling those impacted by organizational stressors at the macro, intermediate, and micro levels of several police agencies. Justice Professional, 12, 443-469. http://dx.doi.org/10.1080/1478601X.2000.9959562

Liberman, A. M., Best, S. R., Meltzer, T. J., Fagan, J. A., Weiss, D. S., \& Marmar, C. R. (2002). Routine Occupational distress in Police. Policing: An International Journal of Police Strategies \& Management, 25, 421-441. http://dx.doi.org/10.1108/13639510210429446 
Lord, V. B. (1996). An impact of community policing: Reported stressors, social support, and strain among police officers in a changing police department. Journal of Criminal Justice, 15, 361-368.

Malloy, T. E., \& Mays, L. (1984). The police stress hypothesis: A critical evaluation. Criminal Justice and Behavior, 11, 197-224. http://dx.doi.org/10.1177/0093854884011002004

Margolis, B., Kroes, W., \& Quinn, R. (1974).Job Stress: An unlisted occupational hazard. Journal of Occupational Medicine, 16(10), 659-661.

Maslach, C., \& Jackson, S. E. (1979). Burned out Cops and their families. Psychology Today, 12(12), 59-62.

Mathias, B., Cardin, M., \& Peggilee, W. (2010). Enhancing emotion regulation skills in police officers: results of a pilot controlled study. Behaviour Therapy, 41, 329-339. http://dx.doi.org/10.1016/j.beth.2009.08.001

Maynard, E., Peter, N., Maynard, E., Hamilton, I., \& David, S. (1980). Family Life and the Police Profession: Coping Patterns Wives Employ in Managing Job Stress and the Family Environment. Family Relatons, 29, 495-501. http://dx.doi.org/10.2307/584464

McCafferty, L., Francis, D. D., \& McCaffertt, M. J. (1990), Posttraumatic Stress Disorder in the Police: Paradigm of Occupational Stress. Southern Medical Journal, 83(1/5), 543-547.

Morash, M., \& Haarr, R. N. (1995). Gender, workplace problems, and stress in policing. Justice Quarterly, 12(1), 113-140. http://dx.doi.org/10.1080/07418829500092591

Norvell, N., Belles, D., \& Hills, H. (1998). Perceived stress levels and physical symptoms in supervisory law enforcement personnel. Journal of Police Science and Administration, 16, 75-79.

Reinecko, S., Runde, B. B., Weiss, U., Hueft, G., \& Bar, O. (2007). Quality of psychological strain in police work-development of a taxonomy of sources of stress. Psychosom Medicine Psychotherapy, 53(1), 45-52.

Ramachandruni, S., Handberg, E., \& Sheps, D. S. (2004). Acute and chronic psychological stress in coronary $\begin{array}{lllll}\text { disease. } & \text { Current } & \text { Opinion }\end{array}$ http://dx.doi.org/10.1097/01.hco.0000132321.24004.25

Scrivner, E. M. (1994). The Role of Police Psychology in Controlling Excessive Force. Washington, DC: U. S. Department of Justice, National Institute of Justice.

Selye, H. (1978). The stress of police work. Police Stress, 1(1), 7-8.

Sever, M., \& Cinoglu, H. (2010). American Polisinde İş Stressinden Kaynaklanan Aile içi Șiddet Olaylarinin Sosyolojik ve İstatisksel Analizi. Polis Bilimleri Dergisi (Turkish Journal of Police Studies), 12(1), 125-146.

Sewell, J. D. (1981). Police stress. FBI Law Enfgorcement Bulletin, 50, 7-11.

Sigler, T. Robert, Wilson, N. C., \& Allen, Z. (1991). Police stress and teacher stress at work and home. Journal of Criminal Justice, 19, 361-370. http://dx.doi.org/10.1016/0047-2352(91)90033-R

Silbert, M. H. (1982). Job Stress and Burnout of new Police officers. The Police Chief, $46-48$.

Singleton, G. W., \& Teahan, J. (1978). Effects of job-related stress on the physical and psychological adjustment of police officers. Journal of Police Science and Administration, 6, 355-361.

Stevenson, T. M. (1988). Stress among police officers: Burnout and its correlates. California School of Professional Psychology.

Storch, J. E., \& Panzarella, R. (1996). Police stress: State-trait anxiety in relation to occupational and personal stressors. Journal of Criminal Justice, 24, 99-107. http://dx.doi.org/10.1016/0047-2352(95)00058-5

Stotland, E., \& Pendleton, M. (1989). Workload, stress and strain among police officers. Behavioral Medicine, 15, 5-18. http://dx.doi.org/10.1080/08964289.1989.9935146

Stratton, J. G. (1978). Police Stress: An overview. The Police Chief, 58-62.

Teahan, J. E. (1975). A longitudinal study attitude shifts among Black and White police officers. Journal of Social Issues, 31, 47-55. http://dx.doi.org/10.1111/j.1540-4560.1975.tb00739.x

Terry, D. J., \& Jimmieson, N. L. (1999). Work control and employee well-being: A decade review. In C. L. Cooper \& I. T. Robertson (Eds.), International review of industrial and organizational psychology. Chichester, UK: Wiley.

Violanti, J. M., \& Aron, F. (1993). Sources of police stressors, job attitudes and psychological distress. 
Psychological Reports, 72, 899-904. http://dx.doi.org/10.2466/pr0.1993.72.3.899

Violanti, J. M., \& Aron, F. (1994). Ranking police stress. Psychological Reports, 75, 824-826. http://dx.doi.org/10.2466/pr0.1994.75.2.824

Violanti, J. M., Burchiefel, C. M., Miller, D. B., \& Andrew, M. E. (2006). One Buffalo Cardio-Metabolic Occupational Police Stress (BCOPS) pilot study methods and participant characteristics. Annals of Epidemiology, 16, 148-156. http://dx.doi.org/10.1016/j.annepidem.2005.07.054

Walker, M. (1997). Conceptual and methodological issues in the investigation of occupational stress: A case study of police officers deployed on body recovery duty. Policing and Society, 7, 1-17. http://dx.doi.org/10.1080/10439463.1997.9964761

Wang, H. X., Leineweber, C., Kirkeeide, R., Svane, B., Schenck-Gustafsson, K., Theorell, T., \& Orth-Gomer, K. (2007). Psychosocial stress and atherosclerosis: Family and work stress accelerates progression of coronary disease in women. Journal of Internal Medicine, 261(3), 245-254. http://dx.doi.org/10.1111/j.1365-2796.2006.01759.x

Washington, B. (1981). Stress and the female officer. In L. Terrio \& H. J. Vetter (Eds.), Stress and police personnel (pp. 142-147). Needham Heights, MA: Allyn and Bacon.

Wexler, J. G., \& Logan, D. D. (1983). Sources of stress among women police officers. Journal of Police Science and Administration, 11, 46-53.

White, S. E., \& Marino, K. E. (1983). Job attitudes and police stress: An exploration study of causation. Journal of Police Science and Administration, 11, 264-274.

Wright, K. N., \& Saylor, W. G. (1991). Male and female employees' perceptions of prison work: Is there a difference? Justice Quarterly, 8, 508-524. http://dx.doi.org/10.1080/07418829100091191

Yeşilorman, M. (2003). Stress on Police Officer's and Stress Management. Psychological Reports, 72, 899-904.

Zakir, G., \& Murat, D. (2011). Police Job Stress and Stress Reduction/Coping Programs: The effects on the relationship with spouses. Turkish Journal of Police Studies, 13(3), 19-38.

\section{Copyrights}

Copyright for this article is retained by the author(s), with first publication rights granted to the journal.

This is an open-access article distributed under the terms and conditions of the Creative Commons Attribution license (http://creativecommons.org/licenses/by/3.0/). 